\title{
Simulasi Perbaikan System Maintenance dengan Pendekatan Konsep Lean Maintenance
}

\author{
$\left(\operatorname{rfan}^{1)^{\star}}\right.$, Muhammad Ikhsan Hamdy ${ }^{2)}$ \\ 1,Jurusan Teknik Industri, Fakultas Sains dan Teknologi, UIN Sultan Syarif Kasim Riau \\ JI. HR. Soebrantas No. 155 Simpang Baru, Panam, Pekanbaru, 28293 \\ Naskah diterima 27/02/2019; direvisi 17/04/2019; disetujui 22/04/2019 \\ doi: https://doi.org/10.24843/JEM.2019.v12.i01.p03
}

\begin{abstract}
Abstrak
PT. Perkebunan Nusantara V mengolah kelapa sawit yang menghasilkan Crude Palm Oil (CPO) dengan produksi 60-ton TBS/jam. Proses produksi yang berlangsung di Perusahaan sering mengalami pemberhentian yang diakibatkan oleh tingginya frekuensi kerusakan mesin thresher dikarenakan sistem perawatan yang belum optimal menyebabkan waktu penundaan (Down Time) 2-3 jam untuk proses perbaikan di mesin tersebut. Hal ini dapat dilihat pada data kondisi mesin thresher tahun 2018 yaitu terdapat 18 kali komponen mesin yang harus mengalami perawatan di luar dari perawatan mesin. Permasalahan ini bisa terjadi 4-5 kali dalam 1 bulan berdampak buruk pada perusahaan yaitu menurunkan jumlah rendemen. Maka dari itu pada penelitian ini akan dilakukan penentuan aktifitas perawatan mesin tresher agar kerusakan pada mesin dapat diminimalisir dengan pendekatan Failure Mode Effect Analysis (FMEA) dan Realibility Centered Maintenance (RCM). Dari hasil FMEA terhadap 18 komponen mesin tresher dengan RPN terbesar adalah Gearbox dengan nilai 648 poin. Selanjutnya dari hasil RCM dengan aktifitas perawatan schedule on condition dan schedule on restoration task terdapat 9 komponen. Untuk hasil dari MVSM pada proses penggantian komponen mesin tresher terdapat delay maka dilakukan simulasi arena dan penjadwalan penggantian komponen mesin, maka nilai efisiensi penggantian meningkat untuk komponen Gearbox dari 40\% naik menjadi 54,26\%.
\end{abstract}

Kata kunci: FMEA, MVSM, RCM, RPN, Simulasi Arena.

Abstract

PT. Perkebunan Nusantara V processes oil palm which produces Crude Palm Oil (CPO) with a production of 60 tons of FFB / hour. The production process that takes place at the Company often has a stop caused by the high frequency of damage to the engine thresher because the maintenance system that has not been optimal causes a delay time (Down Time) of 2-3 hours for the repair process on the engine. This can be seen in the data on the condition of the thresher engine in 2018, which is 18 times the engine components that have to be treated outside the engine maintenance. This problem can occur 4-5 times in 1 month which has a negative impact on the company, namely reducing the amount of yield. Therefore, this research will determine the tresher engine maintenance activities so that damage to the engine can be minimized using the Failure Mode Effect Analysis (FMEA) approach and Reliability Centered Maintenance (RCM). From the results of the FMEA on the 18 components of the tresher engine with the largest RPN is Gearbox with a value of 648 points. Furthermore, from the RCM results with maintenance schedule on condition activities and schedule on restoration tasks there are 9 components. For the results of MVSM in the replacement process of tresher engine components there is delay, then an arena simulation and scheduling of engine components are replaced, then the value of replacement efficiency increases for Gearbox components from $40 \%$ to $54.26 \%$.

Keywords: FMEA, MVSM, RCM, RPN, Arena Simulation.

\section{Pendahuluan}

Proses produksi yang berlangsung di PT. Perkebunan Nusantara V Sei Galuh sering mengalami pemberhentian ketika produksi berlangsung. Faktor yang menyebabkan masalah proses produksi sering terhenti diakibatkan oleh tingginya frekuensi kerusakan mesin dikarenakan sistem perawatan yang belum optimal. Adapun mesin yang mengalami kerusakan yang dimaksud adalah mesin tresher. Mesin Thresher adalah alat yang digunakan untuk pemilahan jenjang dengan buah setelah proses pemilahan. Mesin ini berfungsi sebagai pemisahan antara buah sawit dan tandannya. Umumnya di stasiun tersebut mempunyai 3-unit mesin, 2 thresher biasa dan 1 double thresher.

Ketika mesin thresher mengalami kerusakan menyebabkan waktu penundaan (Down Time) proses produksi yang cukup lama yaitu memakan waktu 2-3 jam untuk proses perbaikan di mesin tersebut. Pada tahun 2018 terdapat 18 kali komponen mesin yang harus mengalami perawatan di luar dari perawatan mesin. Pada saat penggantian komponen dari mesin tresher ini yang menyebabkan kegiatan non value added. Hal ini disebabkan karena waktu penggantian komponen yang tidak tepat karena dilakukan pada saat mesin sedang bekerja. Selain itu, adanya waktu menunggu (waiting time) untuk melakukan penggantian komponen pada mesin tresher. Permasalahan ini bisa terjadi 4-5 kali dalam 1 bulan, yang mana dapat berdampak buruk pada perusahaan yaitu menurunkan jumlah rendemen yang didapatkan.

Saat melakukan wawancara pada operator mesin Thresher kerusakan yang sering terjadi adalah Gearbox Theresser dan Under Theressing. Hal ini terjadi karena sisi-sisi pintu dari kotoran minyak yang lengket dan sampah-sampah yang menumpuk pada Under Theressing. Selain itu, sering terjadi keausan akibat gesekan yang terjadi di Gearbox Theresser, keausan ini diakibatkan oleh kurangnya pelumasan diantara poros komponen mesin.

Langkah yang dilakukan untuk menyelesaikan permasalahan tersebut pada mesin thresher di PT. Perkebunan Nusantara V Sei Galuh Kampar adalah, pertama dengan melakukan pemilihan tindakan perawatan yang tepat dari masing-masing komponen yaitu mengurangi kegiatan yang tidak memiliki nilai tambah terhadap proses pergantian ataupun 
pembersihan dapat menggunakan metode MVSM dan metode RCM. Kedua dengan melakukan pemilihan tindakan perawatan yang tepat dari masing-masing komponen yang memiliki nilai Risk Priority Number (RPN) yang tinggi menggunakan metode FMEA dan menggunakan metode RCM. Sedangkan untuk mengurangi atau menghilangkan waiting time yang terlalu lama, maka digunakanlah software simulasi arena.

\subsection{Maintenance}

FMEA adalah jenis desain dan teknologi untuk menganalisis keandalan pencegahan, yang merupakan formula yang sistematis terstruktur untuk mengidentifikasi modus kerusakan yang potensial dalam desain atau manufaktur, kemudian mempelajari pengaruh kerusakan pada sistem, kemudian mengambil langkah-langkah yang diperlukan untuk mengkoreksi dan sebagai metode pencegahan sementara yang mengarah pada masalah dalam sistem keandalan (Effendi,2015).Dari hasil FMEA maka dilakukan penentuan aktifitas perawatan menggunakan metode RCM. Pendekatan RCM adalah kegiatan perawatan yang dilakukan menjadi lebih efektif dikarenakan waktu downtime yang berkurang dan waktu penggunaan mesin akan semakin maksimal digunakan (Moubray, 1997).

Maintenance Value Stream Map (MVSM) adalah metode yang digunakan untuk menggambarkan alur kegiatan perawatan yang dikembangkan dari VSM untuk mengidentifikasi pemborosan. Pemborosan tersebut terjadi pada setiap kegiatan perawatan yang tidak memiliki nilai tambah terhadap proses perawatan tersebut (Kurniawati dkk, 2017). Dalam proses metode MVSM terbagi menjadi 2 proses yaitu proses sebelum dilakukan perbaikan (current state map) dan setelah dilakukan perbaikan (future State Map). Setelah mengidentifikasi kegiatan yang tidak memiliki nilai tambah pada current state map selanjutnya membuat alur kegiatan baru yang sudah diminalisir kegiatan yang tidak memiliki nilai tambah pada future state map berdasarkan analisa diagram sebab akibat (Kanaan, 2015). Pada tahapan analisis fishbone diagram merupakan tahapan yang digunakan mencari penyebab terjadinya pemborosan saat aktivitas perawatan digambarkan pada current state map. Berdasarkan hasil pengamatan dan wawancara terhadap perusahaan maka didapatkan bentuk pemborosan yaiu aktivitas delay (Kurniawati, 2017).

\subsection{Simulasi Arena}

Simulasi dengan arena dapat mempresentasikan sebuah sistem produksi dan membangun model eksperimen dengan menggunakan model-model yang menyatakan proses atau logika dalam system. Metode simulasi telah banyak digunakan untuk memperbaiki kinerja suatu sistem produksi manufaktur maupun sistem pelayanan/jasa (Riyanto, 2016).

\section{Metode Penelitian}

Penelitian ini melakukan perbaikan perawatan mesin tresher pertama adalah pengumpulan data. Data yang diperlukan untuk pengolahan data adalah data komponen mesin tresher yang mengalami kerusakan selama tahun 2018, komponen-komponen mesin tresher dan data urutan aktifitas perawatan mesin tresher di PT. Perkebunan Nusantara V Sei Galuh Kampar.

Dari data yang di peroleh langkah awal adalah penentuan komponen prioritas menggunakan metode FMEA dari komponen prioritas. Dari komponen prioritas akan diketahui komponen dari mesin genset yang terlebih dahulu perlu untuk dilakukan perbaikan tindakan aktifitas perawatan. selanjutnya dilakukan penentuan tindakan aktifitas perawatan komponen mesin tresher menggunakan metode RCM. Penentuan ini untuk melihat dari komponen mesin tresher yang perlu untuk dilakukan penggantian komponen yang dilakukan secara berkala.

Perbaikan aktifitas perawatan komponen mesin tresher dilakukan dengan mengetahui urutan kegiatan perawatan di PT. Perkebunan Nusantara V Sei Galuh Kampar. Adapun urutan kegiatan di Perusahaan ini ditunjukkan dalam Gambar 1.

Dari gambar di atas dapat dilihat proses pertama ketika mesin tresher rusak adalah mengidentifikasi sumber masalah, mengkomunikasikan masalah kepada tim maintenance, mengidentifikasi SDM, mengidentifikasi sumber daya peralatan dan komponen yang dibutuhkan, mempersiapkan perintah kerja, melakukan perbaikan mesin dan melakukan inspeksi terhadap komponen yang di ganti apakah sudah berfungsi seperti semula.

Setelah mendapatkan alur kegiatan perawatan, maka dilakukan perhitungan efisiensi perawatan dengan menggunakan current state map. Dari hasil yang di peroleh, maka dilakukan analisa penyebab masalah pada proses perawatan. Dan yang terakhir adalah pembuatan future state map menggunakan software simulasi arena untuk membandingkan apakah efisiensi perawatan meningkat.

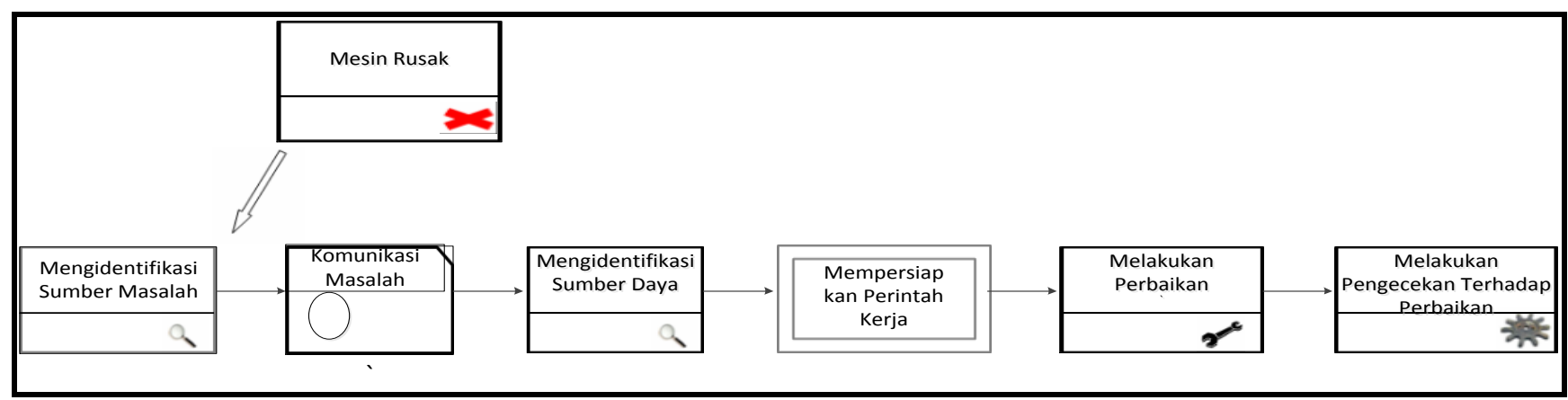

Gambar 1. Alur kegiatan perawatan mesin tresher di PT. Perkebunan Nusantara V Sei Galuh Kampar 


\section{Hasil dan Pembahasan}

Dari pengumpulan data yang telah dilakukan di PT. Perkebunan Nusantara V Sei Galuh Kampar diantaranya: data kerusakan mesin tresher tahun 2018, data komponen mesin tresher DST-100 B dan data alur aktifitas perawatan mesin tresher. Maka dari data tersebut selanjutnya dilakukan pengolahan data untuk mendapatkan hasil yang ingin di capai.

Langkah pertama dalam pengolahan data adalah menentukan masing-masing komponen prioritas menggunakan metode FMEA, hasil yang diperoleh dari penentuan komponen prioritas menggunakan FMEA dapat dilihat pada tabel 1 Nilai RPN dapat dilihat komponen Gearbox memiliki nilai yang terbesar dengan kategori severity sebesar 9 poin, occurance sbesar 9 poin dan detection sebesar 8 poin maka nilai RPN untuk komponen Gearbox sebesar 648, sedangkan untuk komponenkomponen yang memiliki nilai RPN terkecil adalah Gearbox Thresser dengan nilai RPN sebesar 8 poin.

Dari nilai RPN yang di peroleh digunakan untuk melakukan tindakan aktifitas perawatan pada masingmasing komponen mesin tresher menggunakan metode RCM.

\section{Tabel 1. Nilai RPN}

\begin{tabular}{|l|l|c|c|c|c|}
\hline No & Komponen & S & O & D & RPN \\
\hline 1 & Gearbox & 9 & 9 & 8 & 648 \\
\hline 2 & Electromotor & 8 & 8 & 9 & 576 \\
\hline 3 & Housting Crane & 8 & 8 & 8 & 512 \\
\hline 4 & $\begin{array}{l}\text { Gearbox Traveling H. } \\
\text { Crane }\end{array}$ & 8 & 9 & 7 & 504 \\
\hline 5 & $\begin{array}{l}\text { Gearbox Tuang H. } \\
\text { Crane }\end{array}$ & 8 & 9 & 7 & 504 \\
\hline 6 & Electromotor Traveling & 7 & 10 & 7 & 490 \\
\hline 7 & Electromotor Telting & 7 & 10 & 7 & 490 \\
\hline 8 & Electromotor Liveting & 7 & 10 & 7 & 490 \\
\hline 9 & Incinerator & 6 & 10 & 5 & 300 \\
\hline 10 & Under Thressing & 7 & 7 & 6 & 294 \\
\hline 11 & Double Conveyor & 6 & 7 & 6 & 252 \\
\hline 12 & Bunch Cruicher & 5 & 1 & 7 & 35 \\
\hline 13 & Empty Bunch Hopper & 5 & 1 & 6 & 30 \\
\hline 14 & Auto Feeder & 6 & 1 & 5 & 30 \\
\hline 15 & Gearbox Auto Feder & 4 & 1 & 4 & 16 \\
\hline 16 & Fruit Elevator & 3 & 1 & 5 & 15 \\
\hline 17 & Thresser & 3 & 1 & 3 & 9 \\
\hline 18 & Gearbox Thresser & 2 & 1 & 4 & 8 \\
\hline
\end{tabular}

Untuk mendapatkan tindakan aktifitas perawatan komponen maka dilakukan perhitungan menggunakan metode RCM Dari tabel 2 dapat di simpulkan pada perusahaan tindakan aktifitas perawatan mesin tresher menggunakan metode RCM Decition Worksheet terdapat 2 jenis aktifitas perawatan yaitu Scheduled On Condition Task dan Schedule On Restoration Task.

Pada Scheduled on Condition Task terdapat 9 komponen yaitu Housting Crane, Gearbox Traveling $\mathrm{H}$. Crane, Gearbox Tuang H. Crane, Incinerator, Double Conveyor, Bunch Cruicher, Gearbox Auto Feder, Fruit Elevator dan Thresser. Tindakan aktifitas Schedule on Restoration Task melakukan tindakan aktivitas perawatan untuk mengetahui kegagalan potensial yang bisa dicegah dan dideteksi kerusakan komponen dengan cara inspeksi menggunakan suatu alat, karena inspeksi komponen memiliki waktu yang berbeda.

Pada Schedule On Restoration task terdapat 9 komponen yaitu Gearbox, Electromotor, Electromotor Traveling, Electromotor Telting, Electromotor Liveting, Under Thressing, Empty Bunch Hopper, Auto Feeder dan Gearbox Thresser. Tindakan aktifitas Schedule on Restoration task melakukan penggantian terhadap komponen pada mesin tresher yaitu pada interval waktu atau batas usia pemakaian masing-masing komponen meskipun komponen dalam kondisi baik ataupun sudah rusak.

Tabel 2. RCM aktifitas perawatan komponen mesin

\begin{tabular}{|c|c|c|c|}
\hline Komponen & $\begin{array}{l}\text { Proposed } \\
\text { Task }\end{array}$ & $\begin{array}{c}\text { Initial } \\
\text { Interval }\end{array}$ & $\begin{array}{c}\text { Can be } \\
\text { Done By }\end{array}$ \\
\hline Gearbox & $\begin{array}{l}\text { Schedule on } \\
\text { Restoration } \\
\text { Task }\end{array}$ & 480 Jam & Mekanik \\
\hline Electromotor & $\begin{array}{c}\text { Schedule on } \\
\text { Restoration } \\
\text { Task }\end{array}$ & 720 Jam & Mekanik \\
\hline $\begin{array}{l}\text { Housting } \\
\text { Crane }\end{array}$ & $\begin{array}{l}\text { Scheduled on } \\
\text { Condition Task }\end{array}$ & 720 Jam & Mekanik \\
\hline $\begin{array}{l}\text { Gearbox } \\
\text { Traveling H. } \\
\text { Crane }\end{array}$ & $\begin{array}{l}\text { Scheduled on } \\
\text { Condition Task }\end{array}$ & 480 Jam & Mekanik \\
\hline $\begin{array}{l}\text { Gearbox } \\
\text { Tuang H. } \\
\text { Crane }\end{array}$ & $\begin{array}{l}\text { Scheduled on } \\
\text { Condition Task }\end{array}$ & 480 Jam & Mekanik \\
\hline $\begin{array}{l}\text { Electromotor } \\
\text { Traveling }\end{array}$ & $\begin{array}{c}\text { Schedule on } \\
\text { Restoration } \\
\text { Task }\end{array}$ & 240 Jam & Mekanik \\
\hline $\begin{array}{l}\text { Electromotor } \\
\text { Telting }\end{array}$ & $\begin{array}{c}\text { Schedule on } \\
\text { Restoration } \\
\text { Task }\end{array}$ & 240 Jam & Mekanik \\
\hline $\begin{array}{l}\text { Electromotor } \\
\text { Liveting }\end{array}$ & $\begin{array}{l}\text { Schedule on } \\
\text { Restoration } \\
\text { Task }\end{array}$ & 240 Jam & Mekanik \\
\hline Incinerator & $\begin{array}{l}\text { Scheduled on } \\
\text { Condition Task }\end{array}$ & 240 Jam & Operator \\
\hline $\begin{array}{l}\text { Under } \\
\text { Thressing }\end{array}$ & $\begin{array}{c}\text { Schedule on } \\
\text { Restoration } \\
\text { Task }\end{array}$ & 50 Hari & Mekanik \\
\hline $\begin{array}{l}\text { Double } \\
\text { Conveyor }\end{array}$ & $\begin{array}{l}\text { Scheduled on } \\
\text { Condition Task }\end{array}$ & 50 Hari & Operator \\
\hline $\begin{array}{l}\text { Bunch } \\
\text { Cruicher }\end{array}$ & $\begin{array}{l}\text { Scheduled on } \\
\text { Condition Task }\end{array}$ & 100 Hari & Operator \\
\hline $\begin{array}{l}\text { Empty Bunch } \\
\text { Hopper }\end{array}$ & $\begin{array}{c}\text { Schedule on } \\
\text { Restoration } \\
\text { Task }\end{array}$ & 60 Hari & Mekanik \\
\hline Auto Feeder & $\begin{array}{l}\text { Schedule on } \\
\text { Restoration } \\
\text { Task }\end{array}$ & 45 Hari & Mekanik \\
\hline $\begin{array}{l}\text { Gearbox } \\
\text { Auto Feder }\end{array}$ & $\begin{array}{l}\text { Scheduled on } \\
\text { Condition Task }\end{array}$ & 53 Hari & Operator \\
\hline Fruit Elevator & $\begin{array}{l}\text { Scheduled on } \\
\text { Condition Task }\end{array}$ & 840 Jam & Mekanik \\
\hline Thresser & $\begin{array}{l}\text { Scheduled on } \\
\text { Condition Task }\end{array}$ & 672 Jam & Operator \\
\hline $\begin{array}{l}\text { Gearbox } \\
\text { Thresser }\end{array}$ & $\begin{array}{l}\text { Schedule on } \\
\text { Restoration } \\
\text { Task }\end{array}$ & 65 Hari & Operator \\
\hline
\end{tabular}


Setelah mendapatkan aktifitas perawatan selanjutnya melakukan perbaikan perawatan mesin melaui Pendekatan aktifitas perawatan aktual pada mesin tresher menggunakan metode MVSM untuk mengurangi kegiatan-yang dilakukan operator maupun mekanik dalam melakukan penggantian inspeksi terhadap mesin tresher yang tidak memberikan nilai tambah non value added.

Dalam melakukan pengeliminasian kegiatankegiatan pada aktifitas perawatan mesin tresher waktu yang boleh dieliminasi adalah kategori waktu Mean Time to Orginize (MTTO) dan Mean Time to Yield (MTTY). MTTO yaitu waktu yang dibutuhkan untuk mempersiapkan peralatan, material atau komponen mesin dan juga sumber daya manusianya. MTTY yaitu waktu yang dibutuhkan operator dalam memeriksa peralatan yang diperbaiki atau diinspeksi sudah sesuai dengan yang diharapkan agar mesin dapat berfungsi sebagaimana mestinya.

Current state map merupakan gambaran awalan terhadap proses Penggantian komponen mesin tresher di perusahaan ini. Pada current state map ini terdapat penjelasan dari waktu masing-masing kegiatan, kategori waktu kegiatan dan juga alur proses kegiatan dari awal hingga selesai. Proses ini dilakukan pada masing-masing komponen pada mesin tresher yaitu Gearbox dan Incinerator. Gearbox berfungsi untuk memindahkan dan mengubah tenaga dari electromotor yang berputar. Data aktifitas penggantian diambil pada tanggal 1-2 Maret 2019 pada komponen Gearbox. Gambaran current state map ditunjukkan dalam Gambar 2..

Pada gambar 2 terdapat 8 proses kegiatan yang terjadi pada saat proses penggantian komponen Gearbox. Adapun waktu kegiatan yang tidak memberikan nilai tambah terhadap proses penggantian sebesar 105 menit sedangkan kegiatan yang memberikan nilai tambah adalah sebesar 70 menit. Dari nilai waktu yang di peroleh tersebut akan dilakukan perhitungan efisiensi proses penggantian pada komponen Gearbox dengan menggunakan data kategori waktu. Adapun kategori waktu pada proses penggantian komponen Gearbox ditunjukkan dalam Tabel 3.

$$
\begin{aligned}
\% \text { Efisiensi perawatan } & =\frac{\text { MMTR }}{\text { MMLT }} \times 100 \\
& =\frac{70}{175} \times 100=40 \%
\end{aligned}
$$

Dari perhitungan efisiensi perawatan pada proses penggantian Gearbox nilai efisiensi perawatan sebesar $40 \%$ dengan waktu nya sebesar 70 menit, yang artinya dari keseluruhan proses kegiatan perawatan hanya $40 \%$. Incinerator berfungsi sebagai tempat pengumpulan sementara janjangan. Data aktifitas penggantian diambil pada tanggal 1-2 Maret 2019 pada komponen Incinerator. Gambaran current state map ditunjukkan dalam Gambar 3.

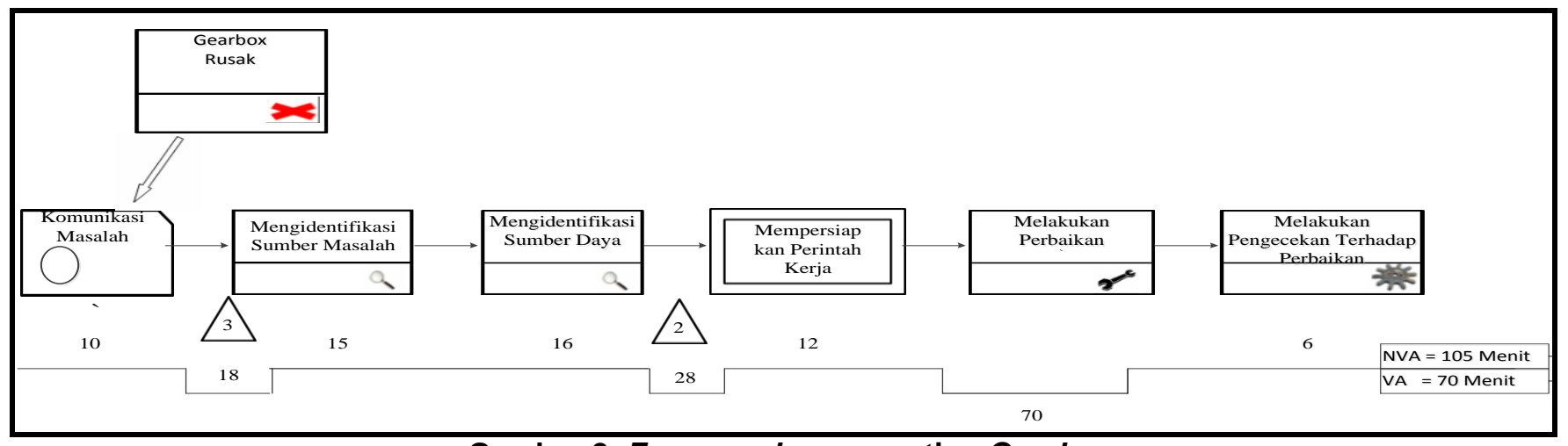

Gambar 2. Framework penggantian Gearbox

\begin{tabular}{|c|c|c|c|}
\hline No & Urutan Kegiatan & Waktu & Kategori Waktu \\
\hline 1 & Gearbox rusak & - & - \\
\hline 2 & Mengkomunikasikan masalah ke tim maintenance & 10 & MTTO \\
\hline 3 & $\begin{array}{l}\text { Delay menentukan dan mempersiapkan pekerja yang } \\
\text { memperbaiki }\end{array}$ & 18 & MTTO \\
\hline 4 & Mengidentifikasi sumber masalah & 15 & MTTO \\
\hline 5 & $\begin{array}{l}\text { Mengidentifikasi sumber daya peralatan dan } \\
\text { komponen yang dibutuhkan }\end{array}$ & 16 & MTTO \\
\hline 6 & Delay akibat komponen tidak ada di penyimpanan & 28 & MTTO \\
\hline 7 & Mempersiapkan perintah kerja & 12 & MTTO \\
\hline 8 & Melakukan perbaikan mesin & 70 & MTTR \\
\hline 9 & $\begin{array}{l}\text { Melakukan inspeksi terhadap komponen yang di ganti } \\
\text { apakah sudah berfungsi seperti semula }\end{array}$ & 6 & MTTY \\
\hline \multicolumn{2}{|c|}{$\begin{array}{l}\text { MLLT } \\
\text { MTTO } \\
\text { MTTR } \\
\text { MTTY }\end{array}$} & $\begin{array}{c}175 \\
99 \\
70 \\
6 \\
\end{array}$ & \\
\hline
\end{tabular}

Tabel 3. Kategori waktu penggantian Gearbox 


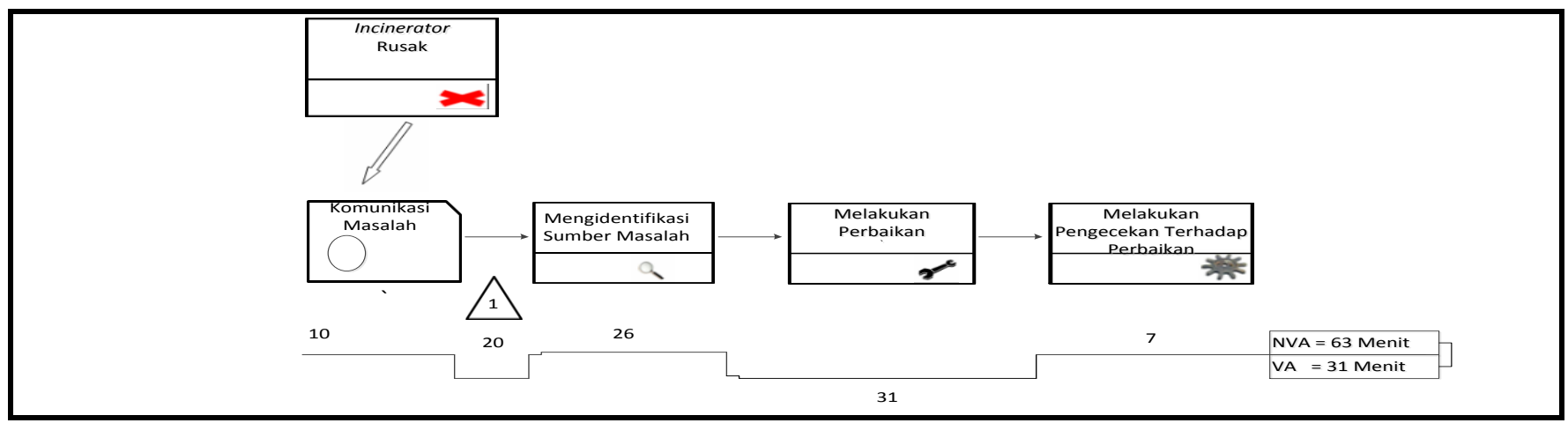

Gambar 3. Framework penggantian Incinerator

Tabel 4. Kategori waktu penggantian Incinerator

\begin{tabular}{|c|l|c|c|}
\hline No & \multicolumn{1}{|c|}{ Urutan Kegiatan } & Waktu & Kategori Waktu \\
\hline 1 & Incinerator rusak & - & - \\
\hline 2 & $\begin{array}{l}\text { Mengkomunikasikan masalah ke tim } \\
\text { maintenance }\end{array}$ & 10 & MTTO \\
\hline 3 & $\begin{array}{l}\text { Delay mempersiapkan peralatan operator untuk } \\
\text { perbaikan }\end{array}$ & 20 & MTTO \\
\hline 4 & Mengidentifikasi sumber masalah & 26 & MTTO \\
\hline 5 & Melakukan perbaikan mesin & 31 & MTTR \\
\hline 6 & Melakukan inspeksi terhadap komponen yang di & 7 & MTTY \\
\hline MLLT & 94 & \multirow{2}{*}{} \\
MTTO & 56 & \\
MTTR & 31 & \multicolumn{2}{c}{} \\
MTTY &
\end{tabular}

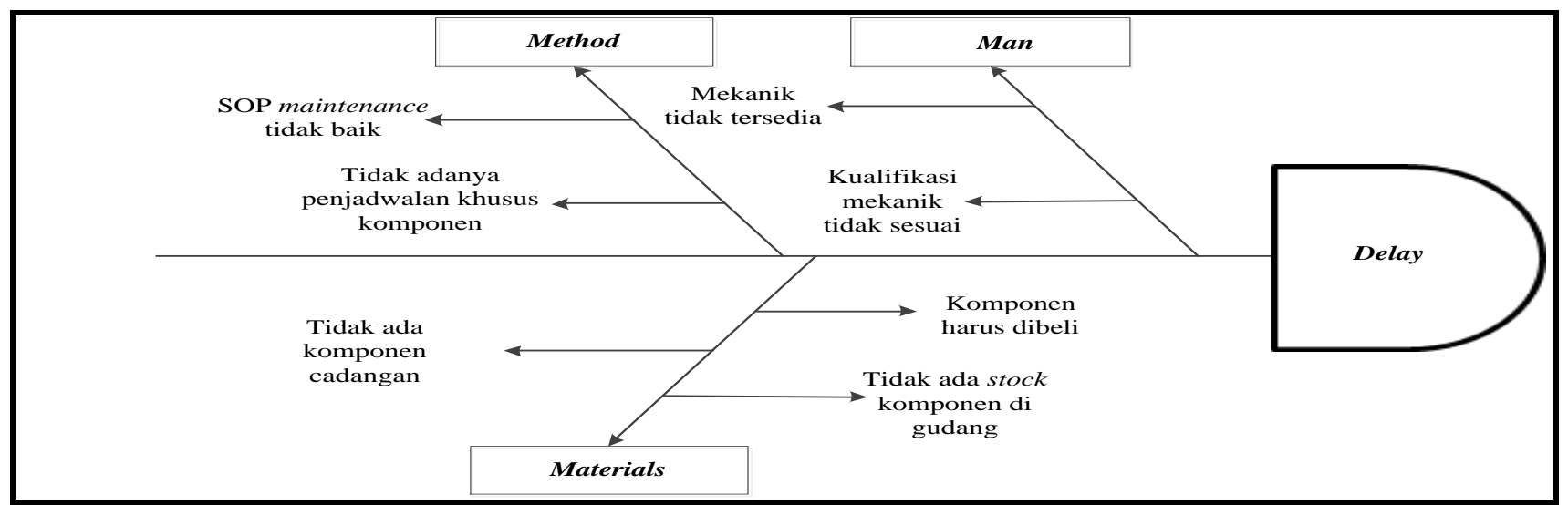

Gambar 4. Diagram Fishbone Delay Mekanik

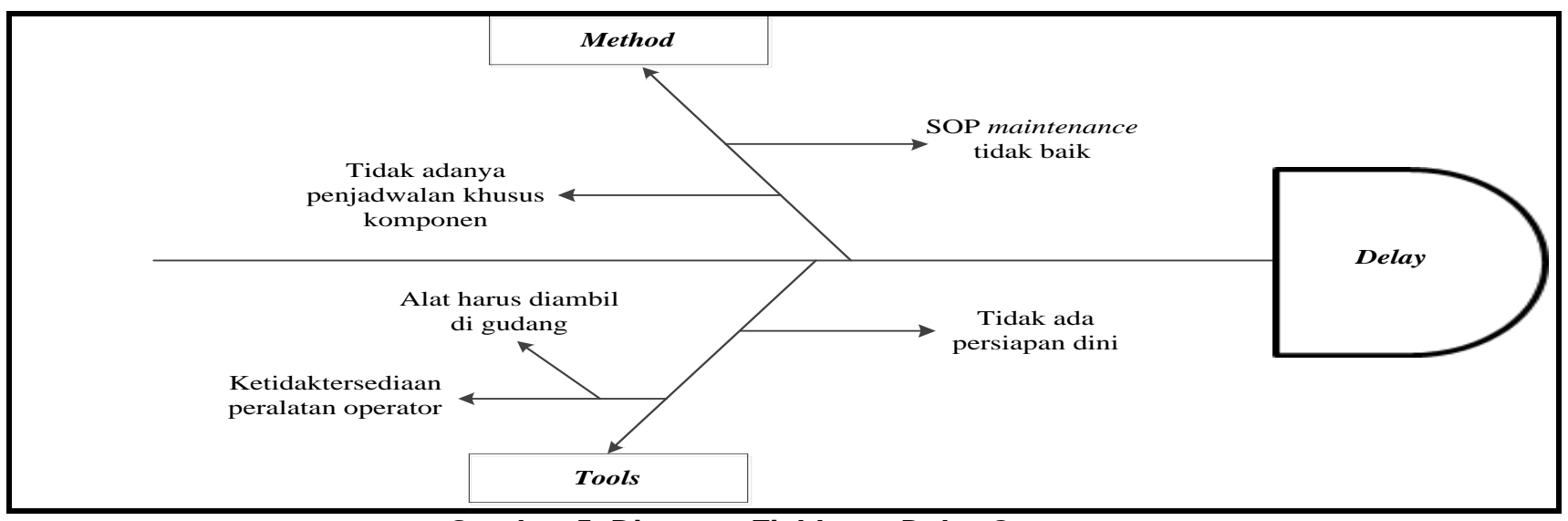

Gambar 5. Diagram Fishbone Delay Operator 


$$
\begin{aligned}
\% \text { Efisiensi perawatan } & =\frac{\text { MMTR }}{\text { MMLT }} \times 100 \\
& =\frac{a 1}{94} \times 100=32,97 \%
\end{aligned}
$$

Dari perhitungan efisiensi perawatan pada proses penggantian Incinerator didapati nilai efisiensi perawatan sebesar $32,97 \%$ dengan waktu 31 menit, dari keseluruhan proses kegiatan perawatan hanya $40 \%$ yang memberikan nilai tambah terhadap penggantian Incinerator.

Selanjutnya dari penggambaran awal current state map dilakukan analisa menggunakan diagram sebab akibat (fishbone) mekanik dan operator. Pada diagram sebab akibat ini menganalisa faktor dari manusia (man), metode kerja (work-method), mesin atau peralatan kerja lainnya (machine/equipment), bahan baku (raw materials) dan lingkungan kerja (work environment). Pada analisa current state map menggunakan diagram sebab akibat untuk menyelesaikan kegiatan non value added lebih ditekankan pada Delay 1 yaitu akibat peralatan operator tidak tersedia Delay 2 yaitu Delay akibat bahan baku atau komponen dan Delay 3 yaitu akibat sumber daya manusia sehingga hasil dari diagram sebab akibat ini dapat menghilangkan Delay yang terjadi. Sebab akibat terjadinya Delay mesin tresher di PT. Perkebunan Nusantara V Sei Galuh Kampar selanjutnya ditunjukkan pada Gambar 4 dan 5.

Dari gambar 4 dapat dilihat terdapat 3 faktor yang menyebabkan Delay 1, Delay 2 dan Delay 3 pada proses maintenance di PT. Perkebunan Nusantara V Sei Galuh Kampar yaitu:

1. Faktor Manusia

Faktor manusia berpengaruh pada terjadinya delay 3 karena SDM mekanik tidak tersedia dan kualifikasi teknisi tidak sesuai yang menyebabkan proses perbaikan mesin tertunda. Untuk mencegah hal ini terjadi, perlu adanya penjadwalan rutin komponen mesin.

\section{Faktor Metode}

Faktor metode yang menyebabkan terjadinya delay yaitu tidak ada penjadwalan untuk masing-masing komponen mesin dan tidak adanya SOP maintenance yang baik, faktor dari metode inilah yang paling berpengaruh terjadinya delay 1 , delay 2 dan delay 3. Untuk menyelesaikan delay ini maka perlu dibuat penjadwalan dan SOP maintenance yang sistematis untuk masing-masing komponen yang diperhitungkan pada metode MVSM. Berikut adalah penjadwalan penggantian komponen mesin tresher PT. Perkebunan Nusantara V Sei Galuh Kampar dapat dilihat pada Tabel 5.

\section{Faktor Material}

Faktor material berpengaruh terhadap terjadinya delay 2 akibat tidak tersedianya komponen cadangan yang dibutuhkan mekanik, tidak ada stock komponen di gudang dan harus melakukan pembelian komponen terlebih dahulu. Untuk menghilangkan delay ini dapat dilakukan safety stock dan pembelian komponen sebelum melakukan maintenance.

\section{Faktor Tools}

Faktor tools sangat berpengaruh terhadap terjadinya delay 1 akibat tidak tersedianya peralatan operator yang dibutuhkan operator. Untuk menghilangkan delay ini dapat dilakukan persiapan dini masing-masing peralatan operator, sehingga dapat melakukan perbaikan mesin tresher tanpa harus menunggu.

Future state map merupakan gambaran proses penggantian mesin tresher di perusahaan setelah dilakukan perbaikan pada current state map. Pada future state map menggunakan software arena dengan penjelasan dari waktu masing-masing kegiatan, kategori waktu kegiatan dan juga alur proses kegiatan dari awal hingga selesai. Tujuan dari software ini adalah menghilangkan delay pada suatu komponen. Proses kegiatan dari future state map ini dilakukan pada komponen mesin tresher.

Pada gambar 6 terdapat 7 proses kegiatan yang terjadi pada saat proses penggantian komponen Gearbox. Adapun waktu kegiatan yang tidak memberikan nilai tambah terhadap proses penggantian sebesar 59 menit dan memberikan nilai tambah adalah sebesar 70 menit. Dari nilai waktu yang di peroleh dilakukan perhitungan efisiensi proses penggantian komponen Gearbox menggunakan data kategori waktu. Perhitungan nilai efisiensi perawatan sebesar $54,26 \%$ dengan waktu nya sebesar 70 menit, yang artinya dari keseluruhan proses kegiatan perawatan hanya $54,26 \%$ yang memberikan nilai tambah terhadap penggantian Gearbox.

Pada gambar 7 terdapat 4 proses kegiatan yang terjadi pada saat proses penggantian komponen Incinerator. Waktu kegiatan yang tidak memberikan nilai tambah terhadap proses penggantian sebesar 43 menit dan memberikan nilai tambah sebesar 31 menit. Selanjutnya dilakukan perhitungan efisiensi proses penggantian komponen Incinerator dengan menggunakan data kategori waktu. Nilai efisiensi perawatan sebesar $41,89 \%$ dengan waktu sebesar 31 menit, jadi keseluruhan proses kegiatan perawatan hanya $41,89 \%$. Keseluruhan proses perbaikan dari aktifitas perawatan mesin mengalami kenaikan efisiensi perawatan mesin pada Tabel 7. 
Tabel 5. Jadwal Pemeliharaan Komponen Mesin PT. Perkebunan Nusantara V Sei Galuh Kampar

\begin{tabular}{|c|c|c|c|c|c|}
\hline \multicolumn{6}{|c|}{ Jadwal Pemeliharaan Komponen Mesin Tresher PT. Perkebunan Nusantara V Sei Galuh Kampar } \\
\hline \multicolumn{3}{|c|}{$\begin{array}{l}\text { Nama Mesin } \\
\text { Tipe Mesin } \\
\text { Power Mesin }\end{array}$} & \multicolumn{3}{|c|}{ Tahun 2019} \\
\hline \multirow{2}{*}{ No } & \multirow{2}{*}{ Nama } & \multirow{2}{*}{ Tindakan } & \multicolumn{3}{|c|}{ Jadwal Pemeliharaan untuk Periode 1Tahun } \\
\hline & & & Pemeliharaan I & Pemeliharaan II & Pemeliharaan III \\
\hline 1 & Gearbox & Schedule on Restoration Task & 480 Jam & 960 Jam & $1440 \mathrm{Jam}$ \\
\hline 2 & Electromotor & Schedule on Restoration Task & 720 Jam & 1440 Jam & $2160 \mathrm{Jam}$ \\
\hline 3 & Housting Crane & Schedule on Condition Task & 720 Jam & 1440 Jam & 2160 Jam \\
\hline 4 & $\begin{array}{l}\text { Gearbox } \\
\text { Traveling } H . \\
\text { Crane }\end{array}$ & Schedule on Condition Task & 480 Jam & 960 Jam & 1440 Jam \\
\hline 5 & $\begin{array}{l}\text { Gearbox Tuang } \\
\text { H. Crane }\end{array}$ & Schedule on Condition Task & 480 Jam & 960 Jam & 1440 Jam \\
\hline 6 & $\begin{array}{l}\text { Electromotor } \\
\text { Traveling }\end{array}$ & Schedule on Restoration Task & 240 Jam & $480 \mathrm{Jam}$ & 720 Jam \\
\hline 7 & $\begin{array}{l}\text { Electromotor } \\
\text { Telting }\end{array}$ & Schedule on Restoration Task & 240 Jam & 480 Jam & 720 Jam \\
\hline 8 & $\begin{array}{l}\text { Electromotor } \\
\text { Liveting }\end{array}$ & Schedule on Restoration Task & 240 Jam & $480 \mathrm{Jam}$ & 720 Jam \\
\hline 9 & Under Thressing & Schedule on Restoration Task & 50 Hari & 100 Hari & 150 Hari \\
\hline 10 & $\begin{array}{l}\text { Empty Bunch } \\
\text { Hopper }\end{array}$ & Schedule on Restoration Task & 60 Hari & 120 Hari & 180 Hari \\
\hline 11 & Auto Feeder & Schedule on Restoration Task & 45 Hari & 90 Hari & 135 Hari \\
\hline 12 & Fruit Elevator & Schedule on Restoration Task & $840 \mathrm{Jam}$ & $1680 \mathrm{Jam}$ & $2520 \mathrm{Jam}$ \\
\hline 13 & Incinerator & Schedule on Condition Task & 240 Jam & $480 \mathrm{Jam}$ & 720 Jam \\
\hline 14 & $\begin{array}{l}\text { Double } \\
\text { Conveyor }\end{array}$ & Schedule on Condition Task & 50 Hari & 100 Hari & 150 Hari \\
\hline 15 & Bunch Cruicher & Schedule on Condition Task & 100 Hari & 200 Hari & 300 Hari \\
\hline 16 & $\begin{array}{l}\text { Gearbox Auto } \\
\text { Feder }\end{array}$ & Schedule on Condition Task & 53 Hari & 106 Hari & 159 Hari \\
\hline 17 & Thresser & Schedule on Condition Task & 672 Jam & 1344 Jam & 2016 Jam \\
\hline 18 & $\begin{array}{l}\text { Gearbox } \\
\text { Thresser }\end{array}$ & Schedule on Restoration Task & 65 Hari & 130 Hari & 195 Hari \\
\hline
\end{tabular}

\begin{tabular}{|l|l|l|l|l|l|l|l|}
\hline & & & & \\
\hline
\end{tabular}




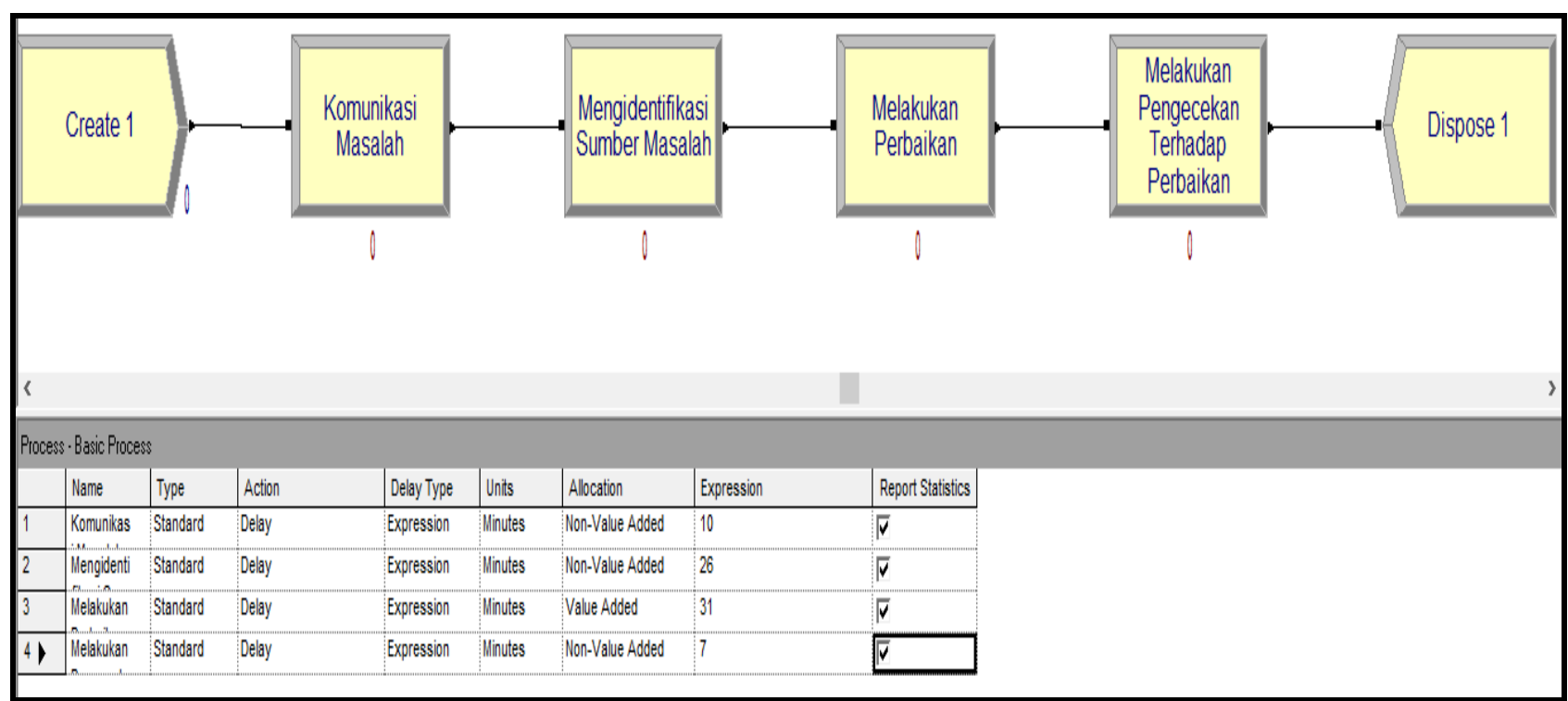

Gambar 7. Future State Map Penggantian Incinerator

Tabel 7. Perbandingan \% efisiensi perbaikan perawatan

\begin{tabular}{|l|c|c|c|}
\hline \multicolumn{1}{|c|}{ Nama Komponen } & $\begin{array}{c}\text { \% Efisiensi Current } \\
\text { State Map }\end{array}$ & $\begin{array}{c}\text { \% Efisiensi Future } \\
\text { State Map }\end{array}$ & $\begin{array}{c}\text { \% Peningkatan } \\
\text { Efisiensi }\end{array}$ \\
\hline Gearbox & 40 & 54,26 & 14,26 \\
\hline Electromotor & 41,66 & 56,52 & 14,86 \\
\hline Housting Crane & 40,64 & 55,75 & 15,11 \\
\hline Gearbox Traveling H. Crane & 36,58 & 51,28 & 14,7 \\
\hline Gearbox Tuang H. Crane & 36,58 & 51,28 & 14,7 \\
\hline Electromotor Traveling & 41,66 & 57,47 & 15,81 \\
\hline Electromotor Telting & 41,66 & 57,47 & 15,81 \\
\hline Electromotor Telting & 41,66 & 57,47 & 15,81 \\
\hline Electromotor Telting & 41,66 & 57,47 & 15,81 \\
\hline Electromotor Liveting & 41,66 & 57,47 & 15,81 \\
\hline Incinerator & 32,97 & 41,89 & 8.92 \\
\hline Under Thressing & 27,77 & 33,89 & 6,12 \\
\hline Double Conveyor & 33,75 & 42,85 & 9,1 \\
\hline Bunch Cruicher & 34,24 & 43,10 & 8,86 \\
\hline Empty Bunch Hopper & 26,08 & 38,29 & 12,21 \\
\hline Auto Feeder & 18,84 & 30,23 & 11,39 \\
\hline Gearbox Auto Feder & 22,05 & 27,77 & 5,72 \\
\hline Fruit Elevator & 20,75 & 31,42 & 10,67 \\
\hline Thresser & 31,52 & 38,15 & 6,63 \\
\hline Gearbox Thresser & 20,40 & 23,80 & 3,14 \\
\hline
\end{tabular}

\section{Simpulan}

Adapun kesimpulan dari penelitian ini adalah terdapat kegiatan non value added yaitu delay 3 dan delay 2 pada aktifitas perawatan mekanik serta delay 1 pada aktifitas perawatan operator. Dengan menggunakan software arena pada Future State Map
MVSM maka dapat menghilangkan delay pada aktifitas perawatan. Selain itu, adanya penjadwalan khusus pada komponen mesin tresher sehingga aktifitas perawatan lebih efisien.

Besar efisiensi sebelum dan sesudah dilakukannya preventive maintenance dengan 
perbandingan \% efisiensi perbaikan perawatan pada komponen mesin tresher. Besar \% peningkatan efisiensi perawatan tertinggi kompon Electromotor, Electromotor Traveling, Electromotor Telting, dan Electromotor Liveting yaitu sebesar $15,81 \%$, sedangkan besar \% peningkatan efisiensi perawatan terendah terjadi pada komponen Gearbox Thresser yaitu sebesar 3,14\%.

Adapun saran mengenai penelitian yaitu bagi pihak perusahaan dapat menjadi masukan dan menerapkan hasil untuk mengurangi permasalahan breakdown mesin tresher dan mengurangi downtime mesin. Diharapkan pada penelitian selanjutnya dapat meminimalisir NVA dari proses-proses perawatan di perusahaan dengan membuat langkah-langkah perbaikan mesin berupa SOP perawatan yang baik dengan pendekatan lean manufacture. SOP yang dimaksud adalah pelaksanaan perawatan mesin tresher dari awal persiapan perbaikan hingga proses pengecekan setelah perbaikan dilakukan.

\section{Daftar Pustaka}

[1] Effendi, M \& Arifin, M. Perbedaan risk priority number dalam failure mode and effect analysis FMEA sistem alat berat heavy duty truck HD 7857. Spektrum industri, volume XII. 2015

[2] Kannan, Soundararajan, et. al. Developing A Maintenance Value Stream Map. Department of Industrial and Information Engineering The University of Tennessee. Knoxville. TN 379962210. 2007.

[3] Kurniawati, Dwi Agustina dan M Lutfan Muzaki. Analisis Perawatan Mesin dengan Pendekatan RCM dan MVSM. Jurnal Optimasi Industri-Vol.16 No. 2(2017) 89-105. 2017.

[4] Moubray, John. Reliability Centered Maintenance II 2nd Edition. Butterworth: Heinemann:Oxford. 1997.

[5] Riyanto, Ong Andre Wahyu. Simulasi Model Kerja pada Departemen Injection untuk Meminimasi Waktu Work-In Process. Prodi Teknik Industri Universitas Wijaya Putra, No. 1-3. 2016 